\title{
Methane fermentation of poultry slaughterhouse waste
}

\author{
Mateusz Wymysłowski, Małgorzata Luczak, Alicja Zawadzka, Mirosław Imbierowicz, \\ Andrzej Chacuk
}

\author{
Technical University of Lodz, Faculty of Process and Environmental Engineering, 90-924 Łódź, ul Wólczańska 213, \\ Poland, e-mail: wymyslow@wipos.p.lodz.pl
}

\begin{abstract}
One of the alternative methods for the treatment of animal by-products is their utilization in biological processes with a simultaneous production of energy-rich biogas. The results of the investigations of methane fermentation of animal waste are discussed in the study. The methane fermentation was carried out at $35^{\circ} \mathrm{C}$. The substrates used in the experiments included poultry heads and muscle tissue. Furthermore, the fermentation residues subjected previously to hydrothermal processing were used as a substrate. The suspension of those substrates in the initial concentration range from $1 \mathrm{~g} \mathrm{TOC} / \mathrm{dm}^{3}$ to $11 \mathrm{~g} \mathrm{TOC} / \mathrm{dm}^{3}$ was used in the process. Additionally, the effect of the preliminary stage of hydrothermal substrate processing on methane fermentation efficiency was assessed. Poultry waste was subjected to thermohydrolysis at the temperature from $100^{\circ} \mathrm{C}$ to $300^{\circ} \mathrm{C}$ and pressure up to $9.0 \mathrm{MPa}$. The efficiency of the methane fermentation was estimated on the basis of biogas generated in the process. The biogas production was between $0.17 \mathrm{Ndm}^{3} / \mathrm{g} \mathrm{TOC}$ and $1.53 \mathrm{Ndm}^{3} / \mathrm{g}$ TOC. In the case of poultry heads, a beneficial impact of hydrothermal processing at the temperatures from $100^{\circ} \mathrm{C}$ to $175^{\circ} \mathrm{C}$ was confirmed. For poultry meat the preliminary thermohydrolysis brought about a decrease of methane fraction in the biogas evolved. The preliminary hydrothermal processing made it possible to meet the requirements of legal regulations for the hygienization of by-products of animal origin. The obtained results allowed us to identify conditions under which the methane fermentation was carried out and which ensured a high level of methanization.
\end{abstract}

Keywords: methane fermentation, poultry waste, thermohydrolysis.

\section{INTRODUCTION}

Animal waste constitutes a serious hazard as it may cause and spread dangerous diseases as well as soil, air or water contamination. In Europe, about 18 million $\mathrm{Mg} /$ year of animal waste is produced and it is estimated that in Poland 1 million tons of animal by-products are generated ${ }^{\mathbf{1}}$.

A widespread method for the treatment of animal byproducts was their processing into meat-bone meal applied as an additive to food preparations used in animal farming. The outbreak of BSE epidemics contributed to the fact that the application of meat-bone meat in animal nutrition was stopped, the necessity to find new methods of animal waste treatment appeared and the costs of waste treatment increased. In Poland, about $400000 \mathrm{Mg}$ of meat-bone meal is produced every year which is used either as soil enhancers or is co-incinerated in energy processes $^{2,3}$.

Due to a high content of proteins and fats, animal waste constitutes a valuable energy material which may be utilized as a substrate in methane fermentation. In this project, the process of methane fermentation was used as a method for the biological treatment of animal waste.

Methane fermentation is a term denoting a set of biochemical processes of anaerobic decomposition of highmolecular organic substances, such as carbohydrates, proteins, fats and their derivatives. As a consequence of these processes, organic substances are decomposed into alcohols or lower organic acids and to methane, carbon dioxide and water ${ }^{4,5}$. Bacteria taking part in the process of methane fermentation are apt to conduct organic substance decomposition in a wide range of temperatures (from $10^{\circ} \mathrm{C}$ to $\left.60^{\circ} \mathrm{C}\right)$.
The aim of the investigations was to define the effectiveness of the methane fermentation of the chosen waste fractions generated in the processes connected with animal slaughter. An important aspect of the investigations undertaken here was the introduction of the stage of preliminary hydrothermal processing of the utilized waste ${ }^{6}$.

\section{EXPERIMENTAL}

In the study anaerobic biodegradation of poultry waste was assessed on the basis of the biogas evolved in the course of the process (a gasometric method). A manometric method based on pressure change measurement under isothermal-isochoric conditions was applied ${ }^{7}$. The investigations were carried out in accordance with the procedure defined in the Polish Standard PN-EN ISO 11734 "Water quality. Evaluation of the ultimate anaerobic biodegradability of organic compounds in digested sludge. A method for the measurement of the biogas production"8.

The process of anaerobic biodegradation was conducted in glass bottles of the nominal volume $0.1 \mathrm{dm}^{3}$ (SCHOTT), equipped with a gas-proof membrane in the form of a disc made of bromobutyl rubber. The pressure inside the bottles was measured using a TESTO 512 meter with a pressure sensor of measuring the range from 0 to $2000 \mathrm{hPa}$ and resolution $1 \mathrm{hPa}$. Figure 1 shows a scheme of the equipment used for the anaerobic biodegradability tests of animal by-products.

The methane fermentation of animal waste was carried out in the medium inoculated with fermented sewage sludge taken from the mesophilic system of a sewage sludge fermentation plant (Wastewater Treatment Plant in Lodz). The sewage sludge collected was subjected to preliminary incubation to decrease the influence of inoculum on biogas production during the experiment. Washed and centri- 


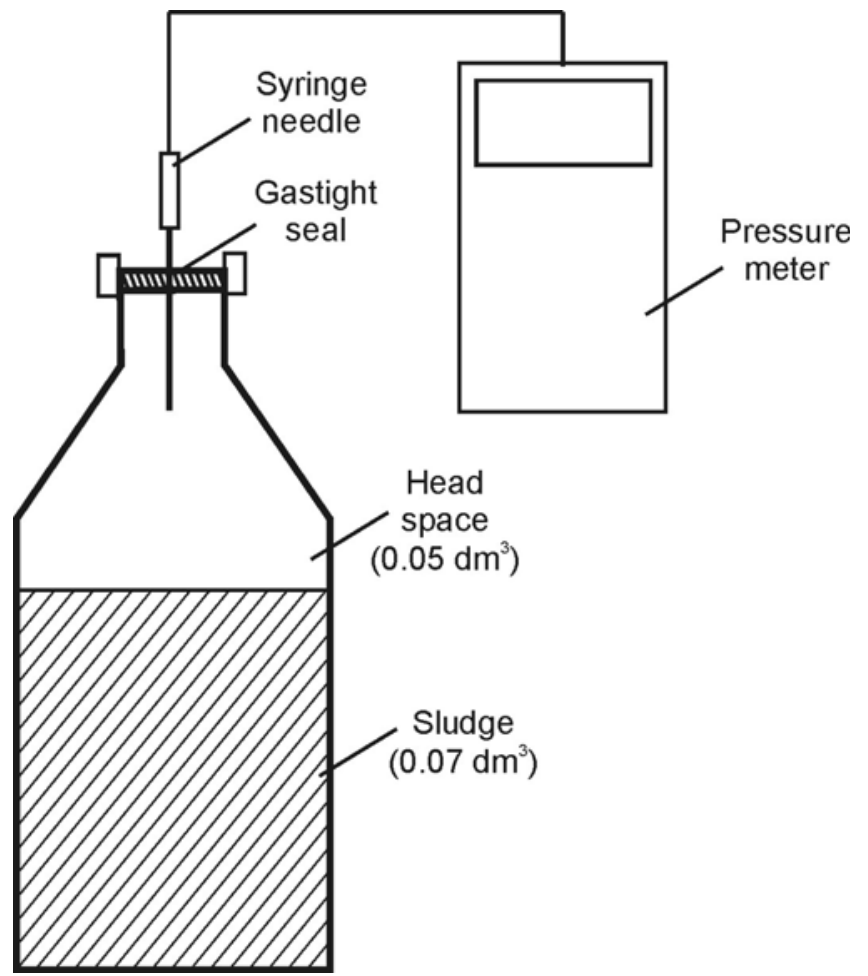

Figure 1. The equipment for the anaerobic biodegradability testing of animal by-products

fuged sewage sludge was located in deaerated broth containing the appropriate set of nutritional elements for the investigations. The total suspension concentration was from 1 to $3 \mathrm{~g} \mathrm{TS} / \mathrm{dm}^{3}$. A previously homogenized substrate was added to an inoculum solution prepared in this way. Each investigated sample was subjected to methane fermentation applying a three-fold repetition - the results presented below are mean values. The fermentation was carried out in the bottles described above, leaving $30 \%$ of free space above the liquid (the volume of fermentation solution was $0.07 \mathrm{dm}^{3}$ ). The tightly closed bottles containing the suspensions of the investigated waste were incubated at $35^{\circ} \mathrm{C}$ for about 60 days. In the course of the process, the pressure in the gaseous volume of the tested vessels was measured which allowed us to determine the quantity of the biogas generated in the process of methane fermentation. Physicochemical analyses of the fermentation suspension were performed determining the $\mathrm{pH}(\mathrm{pH}$ meter - Eurosensor ESAgP-309W electrode), total organic carbon (TOC), total solids (TS) and volatile solids (VS). The composition of the evolving fermentation gas was measured using gas chromatography (Varian CP 3800 with TCD and FID detector).

\section{RESULTS AND DISCUSSION}

In the course of investigations the influence of initial substrate concentration on methane fermentation efficiency was studied. The concentration of investigated substrate was expressed with total organic carbon of the suspension. The initial concentration of total organic carbon in the reaction mass (TOCP) ranged from $1 \mathrm{~g} / \mathrm{dm}^{3}$ to $11 \mathrm{~g} / \mathrm{dm}^{3}$.

For the fermentation of poultry meat whose initial TOC concentration in the fermentation suspension was $1 \mathrm{~g} / \mathrm{dm}^{3}, 2 \mathrm{~g} / \mathrm{dm}^{3}, 3 \mathrm{~g} / \mathrm{dm}^{3}$ and $5 \mathrm{~g} / \mathrm{dm}^{3}$ the increase of biogas evolved with TOC increase was confirmed in the suspension used in the process (Fig. 2). The productivity of biogas expressed as biogas volume per mass unit of organic carbon contained in initial suspension $\left(\mathrm{Ndm}^{3} / \mathrm{g}\right.$ TOC) was equal to $1.53 \mathrm{Ndm}^{3} / \mathrm{g}$ TOC, $1.41 \mathrm{Ndm}^{3} / \mathrm{g}$ TOC, $1.15 \mathrm{Ndm}^{3} / \mathrm{g}$ TOC and $1.13 \mathrm{Ndm}^{3} / \mathrm{g}$ TOC, respectively. In poultry meat fermentation at the concentration of $\mathrm{TOC}_{\mathrm{P}}=2.0 \mathrm{~g} / \mathrm{dm}^{3}$ the biogas production per dry matter unit was equal to $130 \mathrm{Ndm}^{3} / \mathrm{kg}$ TS, while productivity of the biogas per dry organic matter unit was equal to 417 $\mathrm{Ndm}^{3} / \mathrm{kg}$ VS.

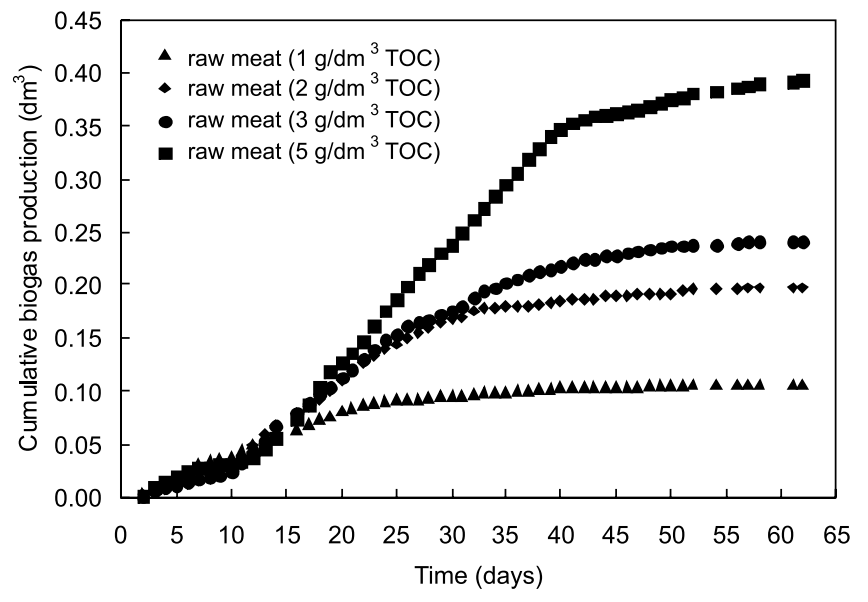

Figure 2. Average cumulative biogas production during the anaerobic digestion of poultry meat $\left(\mathrm{TOC}_{\mathrm{P}}=1.0\right.$ $\left.\mathrm{g} / \mathrm{dm}^{3}, 2.0 \mathrm{~g} / \mathrm{dm}^{3}, 3.0 \mathrm{~g} / \mathrm{dm}^{3}, 5.0 \mathrm{~g} / \mathrm{dm}^{3}, \mathrm{~T}=35^{\circ} \mathrm{C}\right)$

The increase of $\mathrm{TOC}_{\mathrm{P}}$ in the fermented suspension was accompanied by a prolonged process time. For the suspension of poultry meat at the concentration of $\mathrm{TOC}_{\mathrm{P}}=1.0$ $\mathrm{g} / \mathrm{dm}^{3}$ the evolution of fermentation gas stopped after about 25 days, whereas for the suspension at the concentration of $\mathrm{TOC}_{\mathrm{P}}=5.0 \mathrm{~g} / \mathrm{dm}^{3}$ no biogas production was confirmed after about 55 days.

For the fermentation of poultry meat suspension of TOCP concentration higher than $5 \mathrm{~g} / \mathrm{dm}^{3}$, an adaptation phase was prolonged and biogas productivity was decreased (Fig. 3). For the concentration of TOCP $=8.0 \mathrm{~g}$ / $\mathrm{dm}^{3}$ the adaptation phase during which very small evolution of biogas was observed lasted for over 20 days and biogas productivity was very low further in the process. Utilization of poultry meat suspension at the concentration of $\mathrm{TOC}_{\mathrm{P}}=11.0 \mathrm{~g} / \mathrm{dm}^{3}$ caused a disturbance of fermentation. In the literature, ammonium nitrogen content

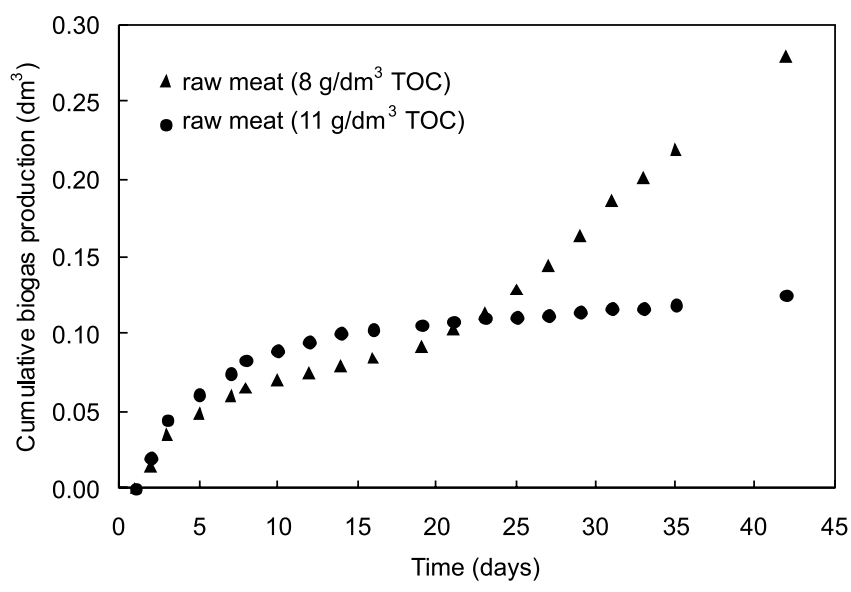

Figure 3. Average cumulative biogas production during the anaerobic digestion of poultry meat $\left(\mathrm{TOC}_{\mathrm{P}}=8.0\right.$ $\mathrm{g} / \mathrm{dm}^{3}, 11.0 \mathrm{~g} / \mathrm{dm}^{3}, \mathrm{~T}=35^{\circ} \mathrm{C}$ ) 
in the fermented suspension equal to $5 \mathrm{~g} / \mathrm{dm}^{3}$ was confirmed for such high initial concentrations of the substrate used for methane fermentation. Ammonia present in the reaction environment in high quantities displays toxicity. It acts adversely on methanogenic bacteria inhibiting their life activity and in extreme cases even the death of this microbial group. Ammonium nitrogen concentration in the fermented suspension up to $3 \mathrm{~g} / \mathrm{dm}^{3}$ may lead to the process inhibition. Ammonium nitrogen content in the quantity greater than $3 \mathrm{~g} / \mathrm{dm}^{3}$ may have a toxic effect on bacterial cultures and may lead to an inhibition of the methane fermentation ${ }^{5}$. The production of big quantities of ammonia during the methane fermentation of the byproducts of animal origin is connected with a high protein content in the material ${ }^{2}$.

Additionally, the influence of preliminary hydrothermal processing on the course of methane fermentation of poultry waste was studied. Thermohydrolysis of the started substrates was conducted in the temperature range from $100^{\circ} \mathrm{C}$ to $300^{\circ} \mathrm{C}$ and at pressures from $0.12 \mathrm{MPa}$ to $8.58 \mathrm{MPa}$.

The impact of preliminary hydrothermal processing of poultry heads on the efficiency of methane fermentation is shown in Figure 4. The quantity of the biogas evolved in the process of methane fermentation was similar to the quantity of the thermohydrolyzed substrate and raw waste. However, an increase of methane content in the biogas produced during the fermentation of heads subjected to hydrothermal processing was observed. Methane fraction in the biogas increased with thermohydrolysis temperature (Table 1). Nevertheless, it was noticed that the adaptation phase of methane fermentation for poultry heads subjected to thermohydrolysis at $200^{\circ} \mathrm{C}$ and pressure 1.62 MPa was prolonged. Table 1 shows the influence of preliminary hydrothermal processing of poultry heads on TOC reduction degree obtained further in the process of

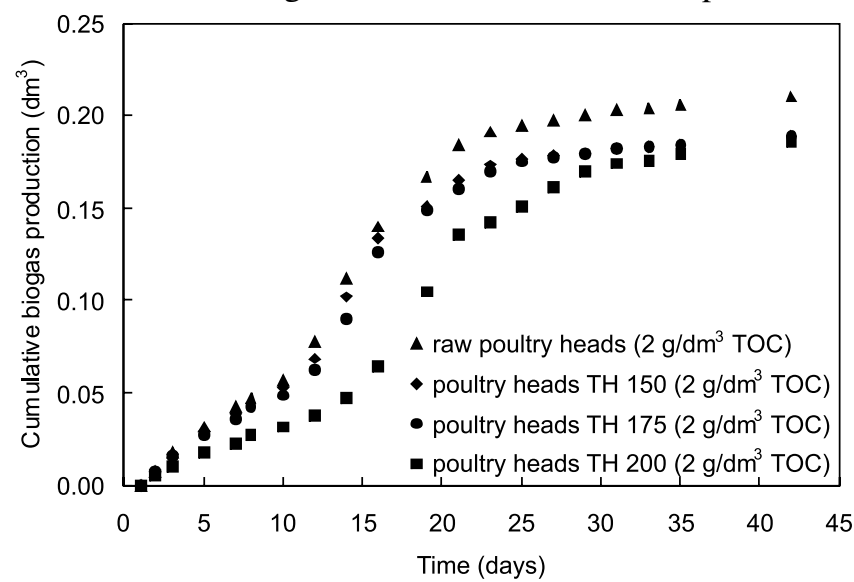

Figure 4. Average cumulative biogas production during the anaerobic digestion of poultry heads $\left(\mathrm{TOC}_{\mathrm{P}}=2.0\right.$ $\mathrm{g} / \mathrm{dm}^{3}, \mathrm{TH}=150^{\circ} \mathrm{C}, 175^{\circ} \mathrm{C}, 200^{\circ} \mathrm{C}, \mathrm{T}=35^{\circ} \mathrm{C}$ ) fermentation. As compared to raw waste, an increase was observed in TOC reduction for the thermohydrolyzed substrate. A maximum TOC reduction was attained for poultry heads subjected to thermohydrolysis at the temperature $175^{\circ} \mathrm{C}$ and pressure $1.07 \mathrm{MPa}$. It was equal to $64.1 \%$ and was by about $30 \%$ higher than the value obtained for raw heads.

For poultry meat $\left(\mathrm{TOC}_{\mathrm{P}}=2.0 \mathrm{~g} / \mathrm{dm}^{3}\right)$ the process of methane fermentation proceeded quicker in the case of the substrate subjected to preliminary hydrothermal processing (Fig. 5). In the hydrothermally treated substrate, biogas evolution stopped after about 25 days, whereas for the raw substrate that time was equal to ca. 35 days. In the case of raw meat a long adaptation phase lasting about 10 days was reported. The quantity of the biogas obtained in the process of methane fermentation of raw meat and of that subjected to thermohydrolysis at $100^{\circ} \mathrm{C}$ at the pressure equal to $0.12 \mathrm{MPa}\left(\mathrm{TOC}_{\mathrm{P}}=5.0 \mathrm{~g} / \mathrm{dm}^{3}\right)$ was the same (Fig. 6). However, the process was found to be quicker in the case of the waste subjected to hydrothermal processing at $100^{\circ} \mathrm{C}$. For poultry meat thermohydrolyzed at $275^{\circ} \mathrm{C}$ (pressure 5.95 MPa) no methane fermentation occurred. The degree of TOC reduction obtained in the methane fermentation of poultry meat was higher in the waste after thermohydrolysis (Table 1). The increase of TOC reduction degree with an increase of thermohydrolysis temperature was observed. It was equal to $62.9 \%$ for the waste subjected to hydrothermal process at $150^{\circ} \mathrm{C}$ (pressure 0.52 $\mathrm{MPa}$ ) and was by about $30 \%$ higher than the TOC reduction degree in raw meat fermentation process. Nonetheless, thermohydrolysis had an observable detrimental influence on methane content in the biogas - a decrease of methane content with an increase of temperature during thermohydrolysis was found.

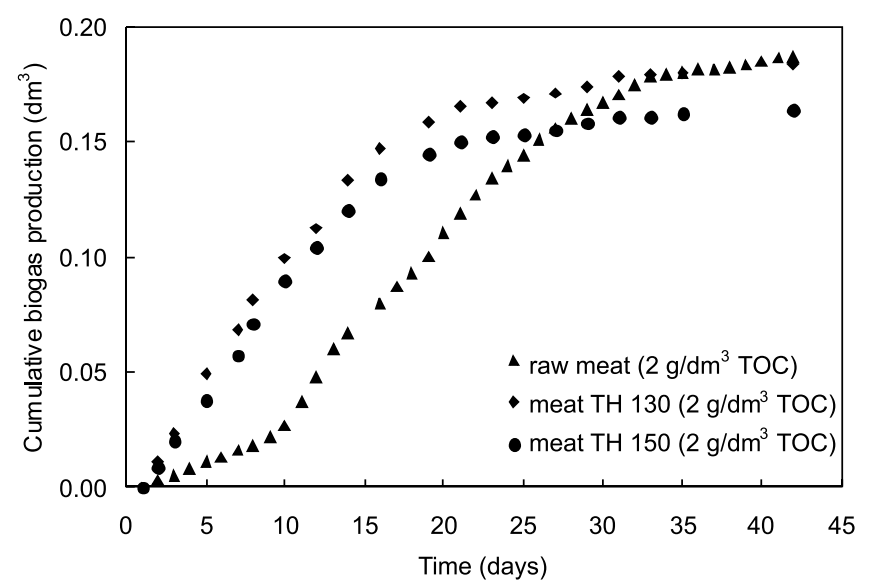

Figure 5. Average cumulative biogas production during the anaerobic digestion of poultry meat $\left(\mathrm{TOC}_{\mathrm{P}}=2.0\right.$ $\mathrm{g} / \mathrm{dm}^{3}, \mathrm{TH}=130^{\circ} \mathrm{C}, 150^{\circ} \mathrm{C}, \mathrm{T}=35^{\circ} \mathrm{C}$ )

Table 1. TOC reduction during anaerobic digestion of poultry heads and poultry meat $\left(\mathrm{T}=35^{\circ} \mathrm{C}\right)$

\begin{tabular}{|l|c|c|c|c|}
\hline Substrate & $\begin{array}{c}\text { TOC } \\
\text { in loading sludge } \\
{[\mathrm{mgC} / \mathrm{kg}]}\end{array}$ & $\begin{array}{c}\text { TOC } \\
\text { in effluent } \\
{[\mathrm{mgC} / \mathrm{kg}]}\end{array}$ & $\begin{array}{c}\text { TOC reduction } \\
{[\%]}\end{array}$ & $\begin{array}{c}\text { Methane content in } \\
\text { biogas } \\
{[\%]}\end{array}$ \\
\hline Raw poultry heads & 2088 & 1056 & 49.4 & 43.45 \\
\hline Poultry heads $\mathrm{TH} 150^{\circ} \mathrm{C}$ & 2342 & 1053 & 55.0 & 49.00 \\
\hline Poultry heads $\mathrm{TH} 175^{\circ} \mathrm{C}$ & 2516 & 903 & 64.1 & 50.66 \\
\hline Poultry heads $\mathrm{TH} 200^{\circ} \mathrm{C}$ & 2516 & 944 & 62.5 & 52.13 \\
\hline Raw poultry meat & 8631 & 4450 & 48.4 & 55.34 \\
\hline Poultry meat $\mathrm{TH} 130^{\circ} \mathrm{C}$ & 2749 & 1357 & 50.0 & 40.86 \\
\hline Poultry meat $\mathrm{TH} 150^{\circ} \mathrm{C}$ & 2804 & 1039 & 62.9 & 36.40 \\
\hline
\end{tabular}




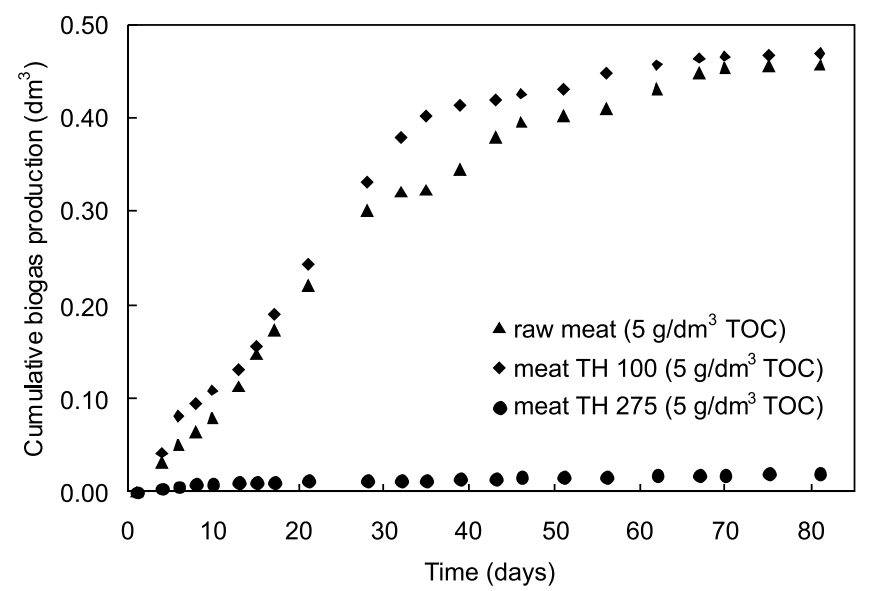

Figure 6. Average cumulative biogas production during the anaerobic digestion of poultry meat $\left(\mathrm{TOC}_{\mathrm{P}}=5.0\right.$ $\mathrm{g} / \mathrm{dm}^{3}, \mathrm{TH}=100^{\circ} \mathrm{C}, 275^{\circ} \mathrm{C}, \mathrm{T}=35^{\circ} \mathrm{C}$ )

At the next stage of the research, the residues from the methane fermentation of poultry waste were hydrothermally treated. The resulting product underwent additionally a methane fermentation process to check if the extra quantities of biogas can be obtained from this substrate. Fermentation residues were divided into two portions, one of which was subjected to hydrothermal processing. Next, both portions underwent methane fermentation. The intensity of biogas evolution during the fermentation of raw and hydrothermally processed residues at the temperature $150^{\circ} \mathrm{C}$ and pressure $0.54 \mathrm{MPa}$ (Fig. 7) was assessed. An increase was observed in the biogas quantity generated in the methane fermentation of the fermentation residues subjected to thermohydrolysis as compared to raw substrate. The quantity of the biogas obtained in the methane fermentation of thermohydrolyzed fermentation residues was by about $75 \%$ higher than in the case of raw substrate. Biogas productivity for raw fermentation residues was $0.33 \mathrm{Ndm}^{3} / \mathrm{g}$ TOC, while for the hydrothermally treated substrate it was $0.59 \mathrm{Ndm}^{3} / \mathrm{g}$. Thermohydrolysis enriches a liquid solution with easily biodegradable organic compounds. The above described processing of fermentation residues contributes to an increase of biogas production. The application of hydrothermal processing of fermentation residues allows us to obtain sterile solid waste.

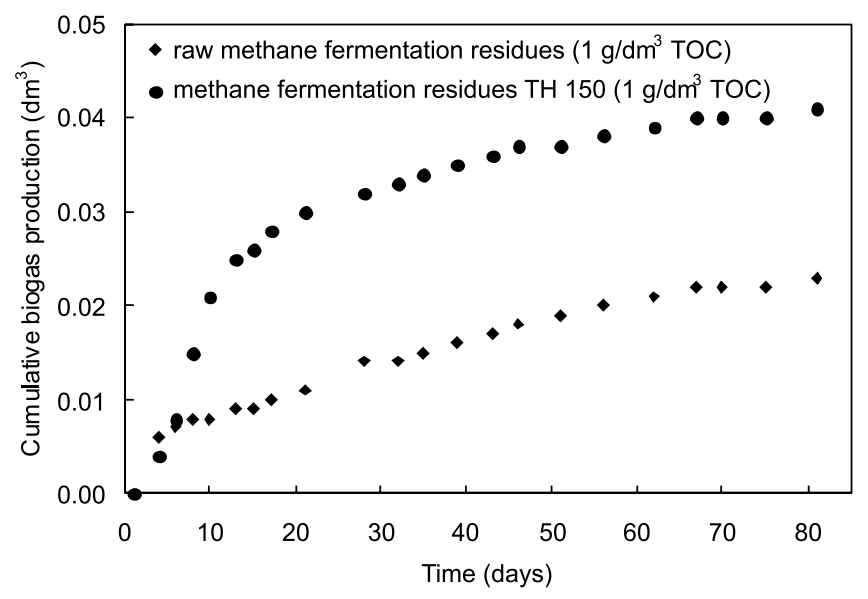

Figure 7. Average cumulative biogas production during the anaerobic digestion of methane fermentation residues $\left(\mathrm{TOC}_{\mathrm{P}}=1.0 \mathrm{~g} / \mathrm{dm}^{3}, \mathrm{TH}=150^{\circ} \mathrm{C}, \mathrm{T}=\right.$ $\left.35^{\circ} \mathrm{C}\right)$

\section{CONCLUSIONS}

The results obtained in this project confirm that the application of methane fermentation as a method to treat by-products of animal origin is justified. The optimal range of initial TOC concentrations of fermented suspensions was from $1 \mathrm{~g} / \mathrm{dm}^{3}$ to $5 \mathrm{~g} / \mathrm{dm}^{3}$. An inhibitory effect of the by-products generated in the process was observed at higher concentrations. The presence of ammonia on a level toxic for the fermentation biocenose was $11 \mathrm{~g} / \mathrm{dm}^{3}$ for TOC concentration in the fermented suspension.

The effect of preliminary hydrothermal processing on methane fermentation efficiency of poultry waste was assessed. A beneficial influence of thermohydrolysis carried out in the temperature range from $100^{\circ} \mathrm{C}$ to $175^{\circ} \mathrm{C}$ was found. Preliminary hydrothermal processing of TOC brought about a decrease of poultry fermentation time. A ca. $30 \%$ increase of TOC reduction was observed in the methane fermentation of thermohydrolyzed substrates as compared to a raw substrate. The preliminary hydrothermal processing of TOC increased methane fraction in the biogas produced during methane fermentation of poultry heads by about $20 \%$.

In the case of fermentation residues a beneficial impact of preliminary hydrothermal processing on methanization efficiency was observed. Biogas quantity obtained in the fermentation of fermentation residues subjected to hydrothermal processing at $150^{\circ} \mathrm{C}$ was by $75 \%$ higher than for raw substrate. Hydrothermal processing of fermentation residues makes it possible to obtain sterile final waste.

\section{LITERATURE CITED}

1. Kowalski, Z. \& Krupa-Żuczek, K. (2007). A model of the waste management. Polish Journal of Chemical Technology, 9, 4, pp. 91 - 97. DOI: 10.2478/v10026-007-0098-4.

2. Edström, M., Nordberg, A. \& Thyselius, L. (2003). Anaerobic treatment of animal byproducts from slaughterhouses at laboratory and pilot scale. Applied Biochemistry and Biotechnology, Vol. 109, pp. 127 - 138. DOI: 10.1385/ ABAB:109:1-3:127.

3. Wzorek, Z., Konopka, M., Cholew, J., Klamecki, G. \& Bajcer, T. (2007). Waste release from meat processing. Polish Journal of Chemical Technology, 9, 3, pp. 91 - 94. DOI: 10.2478/v10026-007-0062-3.

4. Buraczewski, G. (1989). Methane fermentation. Polish Scientific Publishers PWN Warsaw. (in Polish).

5. Jędrczak, A. (2008). Biological waste treatment. Polish Scientific Publishers PWN Warsaw. (in Polish).

6. Regulation (EC) No 1774/2002 of the European Parliament and of the Council of 3 October 2002 laying down health rules concerning animal by-products not intended for human consumption.

7. Guwy, A.J. (2004). Equipment used for testing anaerobic biodegradability and activity. Reviews in Environmental Science and Biotechnology, Vol. 3, pp. 131 - 139. DOI: 10.1007/s11157004-1290-0.

8. Polish Committee for Standardization (PKN). (2003). Polish Standard: Water quality - Evaluation of the "ultimate" anaerobic biodegradability of organic compounds in digested sludge method for measurement of biogas production. PNEN ISO 11734. Warsaw. (in Polish). 